\title{
Draining and liming of ponds as an effective measure for containment of CyHV-3 in carp farms
}

\author{
Agnes Flamm ${ }^{1,5, *}$, Marc Fabian ${ }^{1, *}$, Martin Runge $^{2}$, Kerstin Böttcher ${ }^{3}$, Grit Bräuer ${ }^{3}$, \\ Gert Füllner $^{4}$, Dieter Steinhagen ${ }^{1, * *}$ \\ ${ }^{1}$ Fish Disease Research Unit, Centre of Infectious Diseases, University of Veterinary Medicine, Bünteweg 17, \\ 30559 Hannover, Germany \\ ${ }^{2}$ Lower Saxony State Office for Consumer Protection and Food Safety, Food and Veterinary Institute, Eintrachtweg 17, \\ 30173 Hannover, Germany \\ ${ }^{3}$ Saxony Animal Disease Fund, Löwenstr. 7A, 01099 Dresden, Germany \\ ${ }^{4}$ Saxony State Agency for Environment, Agriculture and Geology, Fisheries Department, Gutsstr. 1, 02699 Königswartha, Germany \\ ${ }^{5}$ Present address: Hesse State Laboratory, Control of Fish Diseases, Schubertstr. 60, 35392 Giessen, Germany
}

\begin{abstract}
Infections of common carp Cyprinus carpio and koi, its coloured morphotypes, with the cyprinid herpesvirus 3 (CyHV-3) can induce severe clinical signs and increased mortality in affected stocks. This may significantly challenge the economic basis of carp farming in Central Europe. To limit virus spread in carp farms, effective disinfection measures for ponds stocked with infected populations are required. In the traditional European pond aquaculture of carp, draining and liming of ponds with quicklime $(\mathrm{CaO})$ up to $\mathrm{pH} 12$ is a well-established disinfection measure against various pathogens. The present field study investigated whether these measures are sufficient for the inactivation of CyHV-3 infectivity in carp ponds. After draining and liming, the ponds were stocked with carp fry from a CyHV-3-negative stock, and 2 ponds were examined for the presence of CyHV-3-specific DNA sequences during the growth period of the carp and in the harvested stock. Wild fish (from the ponds, and feeder and drainage canals) and water samples (from the ponds) were also examined for CyHV-3-specific DNA sequences; and naïve carp were cohabited with wild fish, or exposed to the pondwater samples, to test for the presence of infectious virus. All examined samples remained negative for CyHV-3 throughout the study. This indicates that draining and liming with quicklime can be a suitable disinfection measure for ponds after a CyHV-3 outbreak in carp aquaculture.
\end{abstract}

KEY WORDS: Carp aquaculture $\cdot$ Pond disinfection · Quicklime $\cdot$ Virus containment

\section{INTRODUCTION}

Common carp Cyprinus carpio, raised in pond aquaculture mainly in Asia and Central Europe, is an important food fish and constitutes almost $14 \%$ of the total global freshwater aquaculture production (FAO 2015). Common carp is one of the most variable freshwater fish species and the coloured morphotypes, the koi, are popular ornamental fish worldwide (Barus et al. 2002). Since the late 1990s, populations of common carp have suffered from a serious disease caused by

${ }^{*}$ Authors contributed equally

**Corresponding author: dieter.steinhagen@tiho-hannover.de cyprinid herpesvirus 3 (CyHV-3, also known as koi herpesvirus, KHV). Fish affected by this viral disease develop clinical signs including gill necrosis, skin lesions, exophthalmos or enophthalmos and apathy (Haenen et al. 2004, Rakus et al. 2013), and the mortality rate may reach up to $90 \%$ in aquaculture populations of carp (G. Füllner pers. obs.). Hence, outbreaks of the so-called koi herpesvirus disease (KHVD) cause significant economic losses (Haenen et al. 2004) and have a severe impact on carp aquaculture and koi trade. In Saxony, a major carp-producing area in Ger-

() The authors 2016. Open Access under Creative Commons by Attribution Licence. Use, distribution and reproduction are unrestricted. Authors and original publication must be credited. 
many, carp production declined by $40 \%$ due to CyHV3-related losses (Füllner et al. 2011).

The virus is mainly spread by infected carp and contaminated equipment. In the pond environment, the virus or virus DNA is also detected in effluent water (Matsui et al. 2008, Baumer et al. 2013), in the tissues of several wild fish species (Kempter et al. 2009, Fabian et al. 2013), in benthic invertebrates such as freshwater clams (Kiełpiński et al. 2010) and in piscivorous birds like herons or cormorants (Matsui et al. 2008). From the studies available, it can be concluded that the main reservoir for the virus are infected individuals from the species $C$. carpio. Wild fish species in ponds and contributory or draining canals might also serve as reservoirs, and it remains unclear whether the virus might survive in pond sediment. In environmental water, virus particles remained infective for up to $3 \mathrm{~d}$ (Shimizu et al. 2006) and could be inactivated by ultra violet irradiation, iodophore or chlorine treatment (Kasai et al. 2005). In pond aquaculture, disinfection is frequently done by the application of quicklime $(\mathrm{CaO})$ to increase the sediment $\mathrm{pH}$ up to 12 (Boyd 2003). This measure has the capability to inactivate many fish pathogenic viruses, and therefore treatment with quicklime is, for instance, recommended as a disinfection measure after virus outbreaks in traditional German trout farms (Baur et al. 2010). In the case of CyHV-3 infections, currently no studies are available which examine whether CyHV-3 infectivity is retained in ponds which had been stocked with CyHV-3-infected carp and which had been drained completely and disinfected by the application of quicklime. In the context of a field study on the presence of CyHV-3 in fish and water samples from traditional carp farms (Baumer et al. 2013), we also examined, in a field trial, whether a CyHV-3 infection could be detected in fish or water samples from drained and limed carp ponds when those ponds were re-stocked with uninfected carp fry after disinfection.

\section{MATERIALS AND METHODS}

\section{Field study \\ Fish samples}

Two ponds in different carp farms in Saxony, Germany, were selected for this study. Both ponds had submersed water plants and reed belts which were regularly cut. Via contributing and recipient canals, the ponds were connected to other carp ponds within the carp farm. Both ponds had been stocked with juvenile carp during their first summer (age class C1) and experienced a clinical outbreak of KHVD in summer 2008. The etiology of the disease was confirmed by veterinary and laboratory diagnostics (G. Bräuer, data not shown). Subsequently, the farms were included in the Saxonian program for KHV containment. In all affected ponds, surviving fish were killed, the ponds were completely drained and quicklime was applied on top of the pond sediment at a concentration of $1000 \mathrm{~kg} \mathrm{ha}^{-1}$. After liming, a pH of 12 was measured in wet areas of the ponds, and the ponds were left without water during the winter for a period of at least $6 \mathrm{wk}$. In spring 2009, the ponds were again filled with water and in May, when the $\mathrm{pH}$ of the water was below 8.5, the ponds were stocked with carp fry from a stock which was confirmed as negative for CyHV-3. From the 2 ponds under study, carp were collected at 4 time points during the production period from May to September 2009 and in April 2010, when the ponds were drained completely for harvesting and re-stocking with carp (see Table 1). At each time point, samples from gills, liver, kidney, spleen and brain were taken from the collected carp, the tissues were pooled for individual carp, and an aliquot of $25 \mathrm{mg}$ was taken and examined for the presence of CyHV-3-specific DNA sequences by quantitative PCR (qPCR). In order to rule wild fish out as possible introducers of the disease into ponds, individuals of different wild fish species were collected from contributory and drainage canals of the ponds during the production period in summer 2009 and from the ponds in April 2010 and also analysed for the presence of CyHV-3-specific DNA sequences by qPCR. The wild fish samples consisted of individuals of the families Cyprinidae, Ictaluridae and Percidae (see Table 2). In total, 100 juvenile carp and 145 individuals of different wild fish species were collected from disinfected ponds and their drainage canals and examined for the presence of CyHV-3 as described previously (Fabian et al. 2013).

\section{Water samples}

At each sampling date, 201 of water were collected from the water column (water depth 100-180 cm) of each pond and analysed for the presence of CyHV3 by qPCR analysis, and water samples were exposed to sentinel carp obtained from a virus-free stock in the water. For the qPCR-based detection of CyHV-3, a $100 \mathrm{ml}$ aliquot was taken from each water sample and examined by cation-coated filter concentration 
and qPCR, as described previously (Haramoto et al. 2009, Baumer et al. 2013).

\section{Exposure of sentinel carp}

Water samples and wild fish individuals from the disinfected ponds were tested for CyHV-3 infectivity for carp in laboratory experiments by exposure to sentinel carp. Recipient carp (15 g, 6-9 mo) originated from a single crossing (R8X R3, De Haar Fissen, Wageningen University, NL). The carp were kept and raised under parasite- and virus-free conditions in a laboratory facility supplied with tap water and were confirmed as CyHV-3-free and susceptible to CyHV-3 infection as described previously (Baumer et al. 2013). During the field study, 6 recipient carp were placed into each of the $20 \mathrm{l}$ samples of pond water at the pond site, transported to the laboratory and kept in disinfected glass tanks at $23^{\circ} \mathrm{C}$ as described previously (Baumer et al. 2013). Wild fish collected from the carp ponds during harvesting in spring 2010 were transported to the laboratory, separated according to species and were kept together with 6 recipient carp in disinfected glass tanks at $23^{\circ} \mathrm{C}$ as described previously (Fabian et al. 2013). In all cohabitation experiments, the fish were monitored daily for clinical signs of KHVD for a period of $14 \mathrm{~d}$ and subsequently euthanised by immersion in a bath of $0.5 \mathrm{~g} \mathrm{l}^{-1}$ tricaine methan sulphonate (MS-222, Pharmaq). Then tissue samples from the gill, liver, kidney, spleen and brain were collected and examined for the presence of CyHV-3 by qPCR. All animal experimentation was done according to national and international regulations for experimentation with animals and under approval of the Lower Saxony State Office for Consumer Protection and Food Safety under the reference number 09-1626.

\section{Molecular biological methods}

\section{DNA extraction}

Genomic DNA was isolated from aliquots of $25 \mathrm{mg}$ of pooled tissue or from $100 \mu$ l concentrated water samples using the QIAmp DNA Mini-Kit (Qiagen). In every extraction round, tissue from a CyHV-3-infected carp and from European flounder Platichthys flesus were included as positive and negative controls, respectively. The concentration of obtained DNA was measured with a spectrophotometer (NanoDrop 1000), adjusted to $25 \mathrm{ng} \mathrm{\mu l}^{-1}$ and stored at $-80^{\circ} \mathrm{C}$ until further use.

\section{Quantitative real-time PCR}

The quantitative TaqMan real-time PCR developed by Gilad et al. (2004) was used for analysing tissue and water samples for CyHV-3-specific DNA sequences. The PCR was performed using the primer pair and probe designed by Gilad et al. (2004) and the INTYPE IC-DNA control (Qiagen) as internal amplification control as described previously (Baumer et al. 2013). This assay detected 1-5 copies of virusspecific DNA sequences in the sampled tissue and remained negative when tissues from non-infected individuals or individuals infected with CyHV-1 or CyHV-2 were tested (Bergmann et al. 2010). Using this assay, CyHV-3 DNA could be detected in tissues from all individuals during an acute outbreak of KHVD (Rakus et al. 2013) and in tissues of 1 out of 10 to 10 out of 10 carp collected from latently infected carp populations (Baumer et al. 2013).

\section{RESULTS}

\section{Field samples}

Both carp ponds examined during this study were stocked with carp fry in May 2009, and CyHV-3specific DNA sequences could not be detected in samples from the stocking carp (Table 1). During the growth period of carp, from May to late September 2009, there were no clinical signs of a disease or increased mortalities, and all carp collected during this period appeared clinically healthy upon sampling. No CyHV-3-specific DNA sequences were detected in the tissues of these carp (Table 1). Furthermore, no CyHV-3 was detected in tissues of carp collected during harvesting of the ponds in spring 2010. Likewise, all water samples remained negative during testing for CyHV-3-specific DNA sequences.

No CyHV-3-specific DNA was detected in tissue samples from the wild fish collected from the canals supplying the ponds under study during the 2009 growth period or from the wild fish sampled during draining and harvesting of the ponds in spring 2010.

\section{Sentinel carp}

All sentinel carp kept in water from the examined ponds remained negative for CyHV-3-specific DNA sequences by qPCR (Table 1). Likewise, no CyHV-3specific DNA sequences were detected in tissues 
Table 1. Analysis of samples from farmed carp, water and sentinel carp exposed to water from ponds disinfected with quicklime after an outbreak of a clinical cyprinid herpesvirus 3 (CyHV-3) infection. Temp.: temperature at sampling. No of samples which are CyHV-3 PCR positive (+) or negative (-)

\begin{tabular}{|lccccc|}
\hline $\begin{array}{l}\text { Pond } \\
\text { ID }\end{array}$ & $\begin{array}{c}\text { Sampling date } \\
\text { (dd.mm.yy) }\end{array}$ & $\begin{array}{c}\text { Temp. } \\
\left({ }^{\circ} \mathrm{C}\right)\end{array}$ & $\begin{array}{c}\text { Farmed carp } \\
+/-\end{array}$ & $\begin{array}{c}\text { Water } \\
+/-\end{array}$ & $\begin{array}{c}\text { Sentinel carp } \\
+/-\end{array}$ \\
\hline 7 & 08.05 .09 & 16 & $0 / 10$ & $0 / 2$ & $0 / 6$ \\
& 23.06 .09 & 19 & $0 / 10$ & $0 / 2$ & $0 / 6$ \\
& 29.07 .09 & 21 & $0 / 10$ & $0 / 2$ & $0 / 6$ \\
& 29.09 .09 & 16 & $0 / 10$ & $0 / 2$ & $0 / 6$ \\
& 14.04 .10 & 7 & $0 / 10$ & $0 / 2$ & $0 / 6$ \\
& 16.06 .09 & 18 & $0 / 10$ & $0 / 2$ & $0 / 6$ \\
& 24.07 .09 & 21 & $0 / 10$ & $0 / 2$ & $0 / 6$ \\
& 21.08 .09 & 22 & $0 / 10$ & $0 / 2$ & $0 / 6$ \\
& 25.09 .09 & 15 & $0 / 10$ & $0 / 2$ & $0 / 6$ \\
& 21.04 .10 & 12 & $0 / 10$ & $0 / 2$ & $0 / 6$ \\
\hline
\end{tabular}

Table 2. Samples of wild fish species from ponds and draining canals after disinfection with quicklime after a clinical outbreak of cyprinid herpesvirus 3 (CyHV-3) infection. Number of CyHV-3 PCR-positive individuals/total number of individual. -: fish species not present or no sentinel carp kept together with individuals from this wild fish species

\begin{tabular}{|llccc|}
\hline Common name & Scientific name & Canal & Pond & Sentinel carp \\
\hline Cyprinidae & & & & \\
Gudgeon & Gobio gobio & $0 / 20$ & $0 / 1$ & $0 / 6$ \\
Roach & Rutilus rutilus & $0 / 19$ & $0 / 16$ & $0 / 6$ \\
Rudd & Scardinius erythrophthalmus & $0 / 3$ & - & - \\
Tench & Tinca tinca & $0 / 1$ & $0 / 5$ & - \\
Ictaluridae & & & & \\
Brown bullhead & Ictalurus nebulosus & - & $0 / 18$ & - \\
Percidae & & & & \\
European perch & Perca fluviatilis & $0 / 20$ & $0 / 11$ & $0 / 6$ \\
Ruffe & Gymnocephalus cernua & $0 / 11$ & $0 / 20$ & $0 / 6$ \\
\hline
\end{tabular}

from recipient carp kept together with wild fish species from the examined ponds (Table 2).

\section{DISCUSSION}

In traditional European carp farming, carp ponds are embedded in the landscape and are natural habitats of a large number of aquatic organisms (Bekefi \& Varadi 2007). This includes the presence of a wide range of amphibians, water birds and fish from protected species. Therefore, pond farms are important components of the local ecosystem and landscape (Blayac et al. 2014). In addition, via contributory and recipient pond canals they are closely linked with surrounding habitats (V̌̌etičková \& Adámek 2013). The large surface area of carp ponds, their muddy pond floor and their function as open biosystems, which are closely linked to adjacent aquatic habitats, make disinfection measures after a disease outbreak difficult. Virucidal effects of disinfectants against CyHV-3 were mainly tested in in vitro studies using cell culture-derived virus suspensions, and after application of the disinfectant, the remaining infectivity of the virus was analysed by in vitro testing using a plaque assay (Kasai et al. 2005). Several of the tested substances, such as sodium hypochlorite, iodophores or ethyl ethanol (Kasai et al. 2005), cannot be applied in natural carp ponds. The application of quicklime to the pond sediment is traditionally used in several pond-farming systems as an economic and effective disinfectant (Boyd 2003). The main effect of the quicklime treatment is an increase in soil or water $\mathrm{pH}$, and many viruses including $\mathrm{CyHV}-3$ were found to be inactivated at a $\mathrm{pH}$ of 12 (Roberts 2001, Neukirch 2003). The results of the present study indicate that draining and liming can be effective measures for the disinfection of a pond after a clinical outbreak of CyHV-3 disease.

All carp collected from the ponds after the ponds had been treated and re-stocked with uninfected carp fry remained negative for CyHV-3-specific DNA sequences. Our study was performed in production ponds in carp farms within the framework of a containment programme conducted by Saxonian veterinary authorities. Consequently, control ponds (which would not have been limed before re-stocking) could not be included because of legal restrictions. Therefore, on the basis of our data, it cannot be determined whether draining of the ponds without liming would be sufficient to prevent re-infection. There are, however, field observations of outbreaks of clinical KHVD after re-stocking with naïve carp in ponds which were not or not completely limed (K. Boettcher pers. obs.). This suggests that the treatment of pond sediment with quicklime is an important protective factor.

CyHV-3 was not detected in water samples or in wild fish species from the examined ponds or from contributory and recipient canals. Individuals from several wild fish species were collected from the 
examined ponds during draining of the ponds and harvesting of the carp. These wild fish were not stocked by the farmers but had migrated into the ponds from adjacent aquatic habitats, most likely via contributory or recipient canals. Various fish species from the pond environment are considered as possible hosts for CyHV-3 (Kempter et al. 2009, Kiełpiński et al. 2010); hence, fish migrating into treated ponds from adjacent CyHV-3-infected ponds might carry the infection into the treated environment. In the current investigation, these fishes were tested in order to rule them out as possible introducers of the disease into the ponds following treatment. Laboratory infection experiments involving several wild fish species with CyHV-3 (Fabian et al. 2016) and our data presented here indicate, however, that migrating wild fish might only represent a limited to insignificant risk for the spread of a CyHV-3 infection into treated ponds.

Unfortunately, no data are available on the specificity and sensitivity of the diagnostic method we used. Applied real-time PCR was recommended by the German National Reference Laboratory for Koi Herpesvirus Infection at the Friedrich Loeffler Institute, Greifswald, Insel Riems, for the examination of diagnostic samples, because it could detect 1-5 copies of virus-specific DNA sequences in the sampled tissue and remained negative when tissues from noninfected individuals or individuals infected with CyHV-1 or CyHV-2 were tested (Bergmann et al. 2010). Using this assay, CyHV-3 DNA could be detected in tissues from all individuals sampled during an acute outbreak of KHVD (Bergmann et al. 2010) and in tissues of 1 out of 10 to 10 out of 10 carp collected from latently infected carp populations (Baumer et al. 2013). In the present study, a total of 50 carp were examined per pond. Thus, the sample was large enough to detect infected carp at a prevalence of $<5 \%$ and a statistical reliability of $90 \%$ (Petrie \& Watson 2013).

The data presented here confirm for the first time under field conditions the effectiveness of draining and treating ponds with quicklime as a suitable disinfection measure in CyHV-3 containment programs in traditional European carp farms. In ponds treated with such measures, the reoccurrence of a CyHV-3 infection could not be observed. Economic and environmental studies, which were performed in parallel to the current investigations, indicated a low impact of these measures on the fauna and flora of treated habitats. After liming, the prevalence of amphibian species (Gahsche \& Striese 2011, Hutsch 2012) dragonflies (Monzka 2012) water beetles and macrophyte species (Kornek et al. 2014) was not statistically different to ponds without liming. Compared to the high economic losses in farms with clinical outbreaks of KHVD, liming, which prevented disease outbreaks, proved to be cost-effective (Göbel et al. 2011). This suggests that liming of carp ponds up to $\mathrm{pH} 12$ can be a suitable disinfection measure after an outbreak of CyHV-3 infection in a traditional European carp farm.

Acknowledgements. This study was financially supported by the European Fisheries Fund according to regulation (EG) 1198/2006, the Saxony State Ministry of Environment and Agriculture and the Saxony Animal Disease Fund. The data of this manuscript partly formed the basis of 2 doctoral theses accepted by the University of Veterinary Medicine Hannover, Germany, on February 9, 2011 and on February 17, 2016.

\section{LITERATURE CITED}

Barus V, Penaz M, Kohlmann K (2002) Cyprinus carpio (Linnaeus, 1758). In: Banarescu PM, Paepke HJ (eds) The freshwater fishes of Europe, Vol 5/III. AULA-Verlag, Wiebelsheim, p 8-179

Baumer A, Fabian M, Wilkens MR, Steinhagen D, Runge M (2013) Epidemiology of cyprinid herpesvirus-3 infection in latently infected carp from aquaculture. Dis Aquat Org 105:101-108

Baur WH, Bräuer G, Rapp J (2010) Nutzfische und Krebse, Lebensraum, Erkrankungen und Therapie, 3rd edn. Enke, Stuttgart

Bekefi E, Varadi L (2007) Multifunctional pond fish farms in Hungary. Aquacult Int 15:227-233

> Bergmann SM, Riechardt M, Fichtner D, Lee P, Kempter J (2010) Investigation on the diagnostic sensitivity of molecular tools used for the detection of koi herpesvirus. J Virol Methods 163:229-233

Blayac T, Mathé S, Rey-Valette H, Fontaine P (2014) Perceptions of the service provided by pond fish farming in Lorraine (France). Ecol Econ 108:115-123

Boyd CE (2003) Soil and water quality management in shrimp ponds. J Appl Aquacult 13:11-33

Fabian M, Baumer A, Steinhagen D (2013) Do wild fish species contribute to the transmission of koi herpesvirus (KHV) to carp in hatchery ponds? J Fish Dis 36:505-514

Fabian M, Baumer A, Adamek M, Steinhagen D (2016) Short communication: transmission of Cyprinid herpesvirus 3 by wild fish species - results from infection experiments. J Fish Dis 39:625-628

FAO (2015) Cultured aquatic species information programm; Cyprinus cario. Available at: www.fao.org/fishery/cultured species/Cyprinus_carpio/en (accessed 06 Jan 2016)

Füllner G, Steinhagen D, Baumer A, Fabian M and others (2011) Untersuchung zu Infektionswegen der Koi-Herpesvirus-Erkrankung von Karpfen und Untersuchungen zur Auswirkung von KHV-Bekämpfungsmaßnahmen auf Ökonomie und Ökologie. Schriftenreihe LfULG Heft $34 / 2011$

Gahsche J, Striese M (2011) Amphibienkartierung zur Begleitung von Maßnahmen der KHV-Sanierung im Naturschutzgebiet 'Niederspreer Teichgebiet'. In: Füllner G, 
Steinhagen D, Baumer A, Fabian M, Runge M and others (eds) Untersuchung zu Infektionswegen der Koi-Herpesvirus-Erkrankung von Karpfen und Untersuchungen zur Auswirkung von KHV-Bekämpfungsmaßnahmen auf Ökonomie und Ökologie. Schriftenreihe LfULG Heft 34/2011. Sächsisches Landesamt für Umwelt, Landwirtschaft und Geologie, Dresden, p 143-157

Gilad O, Yun S, Zagmutt-Vergara FJ, Leutenegger CM, Bercovier H, Hedrick RP (2004) Concentrations of a Koi herpesvirus (KHV) in tissues of experimentally infected Cyprinus carpio koi as assessed by real-time TaqMan PCR. Dis Aquat Org 60:179-187

Göbel S, Neumann EM, Füllner G (2011) Untersuchungen zu ökonomischen Auswirkungen geeigneter Präventionsund Sanierungsmaßnahmen. In: Füllner G, Steinhagen D, Baumer A, Fabian $M$ and others (eds) Untersuchung zu Infektionswegen der Koi-Herpesvirus-Erkrankung von Karpfen und Untersuchungen zur Auswirkung von KHV-Bekämpfungsmaßnahmen auf Ökonomie und Ökologie. Schriftenreihe LfULG Heft 34/2011. Sächsisches Landesamt für Umwelt, Landwirtschaft und Geologie, Dresden, p 51-140

Haenen OLM, Way K, Bergmann SM, Ariel E (2004) The emergence of koi herpesvirus and its significance to European aquaculture. Bull Eur Assoc Fish Pathol 24: 293-307

> Haramoto E, Kitajima M, Katayama H, Ito T, Ohgaki S (2009) Development of virus concentration methods for detection of koi herpesvirus in water. J Fish Dis 32: 297-300

Hutsch S (2012) Ökologische Untersuchung der Amphibienzönose an einer Versuchsteichanlage im Oberlausitzer Heide- und Teichgebiet (Sachsen), unter besonderer Berücksichtigung der fischereilichen Bewirtschaftung und der Wassergüte. Master thesis, Fakultät Forst-, Geo- und Hydrowissenschaften, Raumentwicklung \& Naturressourcenmanagement, Technische Universität Dresden

Kasai H, Muto Y, Yoshimizu M (2005) Virucidal effects of ultraviolet, heat treatment and disinfectants against koi herpesvirus (KHV). Fish Pathol 40:137-138

Kempter J, Sadowski J, Schutze H, Fischer U and others (2009) Koi herpes virus: Do acipenserid restitution pro-

Editorial responsibility: Mark Crane, Geelong, Victoria, Australia grams pose a threat to carp farms in the disease-free zones? Acta Ichthyol Piscat 39:119-126

Kiełpiński M, Kempter J, Panicz R, Sadowski J, Schütze H, Ohlemeyer S, Bergmann SM (2010) Detection of KHV in freshwater mussels and crustaceans from ponds with KHV history in common carp (Cyprinus carpio). Isr J Aquacult-Bamid 62:28-37

Kornek K, Blau J, Hanspach D, Füllner G, Opitz M (2014) Auswirkungen der Applikation von Brannt-kalk auf einheimische, insbesondere naturschutzbedeutsame Tierund Pflanzenarten an Karpfenteichen. Schriftenreihe LfULG Heft 28/2014

Matsui K, Honjo M, Kohmatsu Y, Uchii K, Yonekura R, Kawabata Z (2008) Detection and significance of koi herpesvirus (KHV) in freshwater environments. Freshw Biol $53: 1262-1272$

Monzka M (2012) Ökologische Untersuchung der Libellenzönose an einer fischereilichen Versuchsteichanlage im Oberlausitzer Heide- und Teichgebiet (Sachsen), unter besonderer Berücksichtigung der Bewirtschaftungsmaßnahmen. Master thesis, Fakultät Forst-, Geo- und Hydrowissenschaften, Raumentwicklung \& Naturressourcenmanagement, Technische Universität Dresden

Neukirch M (2003) Effect of different temperatures and pH values on the infectivity of viruses isolated from koi. In: Padros, F (ed) Diseases of fish and shellfish. $11^{\text {th }}$ International Conference of the EAFP, St. Julians, Malta, p 80 (Abstract)

Petrie A, Watson P (2013) Statistics for veterinary and animal science, $3^{\text {rd }}$ edn. Wiley-Blackwell, Oxford

Rakus K, Ouyang P, Boutier M, Ronsmans $M$ and others (2013) Cyprinid herpesvirus 3: an interesting virus for applied and fundamental research. Vet Res 44:e85

Roberts RJ (2001) Fish pathology, $3^{\text {rd }}$ edn. Saunders, London Všetičková L, Adámek Z (2013) The impact of carp pond management upon macrozoobenthos assemblages in the recipient pond canals. Aquacult Int 21:897-925

Shimizu T, Yoshida N, Kasai H, Yoshimizu M (2006) Survival of koi herpesvirus (KHV) in environmental water. Fish Pathol 41:153-157

Všetičková L, Adámek Z (2013) The impact of carp pond management upon macrozoobenthos assemblages in the recipient pond canals. Aquacult Int 21:897-925

Submitted: January 19, 2016; Accepted: May 23, 2016 Proofs received from author(s): July 6, 2016 